\title{
Pengaruh Customer Relationship Management dan Kepuasan terhadap Loyalitas Nasabah LPD Desa Adat Anggungan di Badung
}

\author{
Ni Putu Nita Santari ${ }^{1}$ \\ I Wayan Suartina ${ }^{2}$ \\ I Made Astrama ${ }^{3}$ \\ ${ }^{1,2,3}$ Fakultas Ekonomi Bisnis dan PariwisataUniversitas Hindu Indonesia \\ Email:nitasantari12@gmail.com
}

\begin{tabular}{|l|l|l|}
\hline Diterima: 21 desember 2020 & Direvisi: 23 desember 2020 & Disetujui: 26 desember 2020 \\
\hline
\end{tabular}

\begin{abstract}
The LPD is a village economic institution that is used to collect and distribute funds in general as well as a source of development financing in almost parts of customary village areas in Bali. Savings customers are the top priority of the LPD in the customary village of anggungan to create Loyalty. In creating customer satisfaction and loyalty, the LPD in the customary village of anggungan is required to implement a good and appropriate strategy, namely Customer Relationship Management (CRM) to increase customer satisfaction and loyalty. The purpose of this study to analyze the effect partially and simultaneously between Customer Relationship Management (CRM) and satisfaction on customer loyalty savings. The population in this study were 1,958 savings customers. The sample was determined based on the Slovin formula with the results obtained by 95 respondents. The results of data analysis indicate that Customer Relationship Management (CRM) and satisfaction simultaneously have a positive and significant effect on customer loyalty. Increasingly improving information technology strategies, namely Customer Relationship Management (CRM) in order to increase customer satisfaction and loyalty savings.
\end{abstract}

Keywords: Customer Relationship Management (CRM), Satisfaction, and Loyalty

\begin{abstract}
ABSTRAK
LPD itu adalah lembaga ekonomi desa yang digunakan untuk menghimpun dan penyaluran dana pada umumnya serta menjadi sumber dalam pembiayaan pembangunan pada hampir sebagian wilayah desa adat di Bali. Nasabah Tabungan menjadi prioritas utama LPD desa adat anggungan untuk menciptakan Loyalitas. Dalam menciptakan kepuasan dan loyalitas nasabah tabungan, LPD desa adat anggungan dituntut untuk menerapkan strategi yang baik dan tepat yaitu Customer Relationship Management (CRM) guna meningkatkan kepuasan dan loyalitas nasabah tabungan. Tujuan penelitian ini menganalisis pengaruh secara parsial dan simultan antara Customer Relationship Management (CRM) dan kepuasan terhadap loyalitas nasabah tabungan. Populasi dalam penelitian ini adalah 1.958 nasabah tabungan. Sampel ditentukan berdasarkan rumus slovin dengan hasil diperoleh 95 responden. Hasil analisis data menunjukkan bahwa Customer Relationship Management (CRM) dan kepuasan berpengaruh positif dan signiifikan secara simultan bersama terhadap loyalitas nasabah tabungan. Semakin meningkatkan strategi teknologi informasi yaitu Customer Relationship Management (CRM) guna meningkatkan kepuasan dan loyalitas nasabah tabungan.
\end{abstract}

Kata Kunci: Customer Relationship Management (CRM), Kepuasan, dan Loyalitas 


\section{PENDAHULUAN}

Pemasaran adalah suatu kegiatan pokok dalam sebuah perusahaan yang harus dilakukan demi kesuksesan, karena terlepas adanya sebuah pemasaran maka semua anggota perusahaan belum tentu akan bisa melakukan kegiatannya. Pemasaran juga dapat dijadikan sebuah ide pokok kegiatan dalam suatu perusahaan karena hal ini memiliki hubungan dengan konsumen yang nantinya akan menjadi lading pemasukan dalam suatu perusahaan. Kotler (2010: 19) menyebutkan bahwa untuk mendapatkan sebuah pelanggan baru diperlukan biaya yang jauh lebih banyak jika dibandingan dengan pelanggan yang sudah dikenal sebelumnya. Pelanggan yang setia (retainedcustomer) tanpa disadari akan merekomendasikan perusahaan tempat yng membuatnya nyaman, sehinggan hal ini dapan meningkatkan loyalitas perusahaan.

Menurut Hastuti (2014), menyebutkan bahwa untuk bertahan hidup dalam sebuah persaingan maka dibutuhkan adanya keberadaan nasabah yang loyal. Loyalitas nasabah dipengaruhi oleh Customer Relationship Management (CRM), hal ini disebabkan karena CRM sangat dibutuhkan dalam rangka menjalin hubungan pelanggan yang benar - benar akrab, sehingga sebuah perusahaan dapat mengetahui banyak hal terhadap pelanggannya.

Menurut Kotler dan Amstrong (2013:36) menyebutkan bahwa pada pemasaran modern, CRM merupakan sebuah konsep atau gagasa yang sangat penting. Jika dilihat dalam cakupan yang lebih besar maka CRM ini adalah sebuah proses yanng dilakukan untuk membangun serta memelihara hubungan anatara pelanggan dengan perusahaan sesuai dengan norma serta nilai-nilai pada kepuasan seorang pelanggan. Rainer dan Cegielski (2013:288) juga menyebutkan, CRM adalah sebuah strategi atau rencana dalam sebuah organisasi yang harus berfokus serta berorientasi pada seorang pelanggan. Menurut Ali Hasan (2013:128), CRM diartikan sebagai sebuah persepsi seorang pelanggan dengan proporsional rasio dari suatu biaya dengan manfaat dari pada seorang pelanggan, rasio uang pada keuntungan yang ada dalam perusahaan serta sebuah hubungan berkelanjuan serta menjadi hubungan yang timbal balik. Selain CRM loyalitas juga dipengaruhi oleh kepuasan dimana Rosy (2018) menyatakan bahwa kepuasan seorang planggan dapat ditentukan melalui bukti kinerja dari produk yang hampir sesuai dengan harapan pembeli.

Berdasarkan pendapat dari Hastuti (2014), menyatakan bahwa untuk bertahan hidup dalam sebuah persaingan maka dibutuhkan adanya keberadaan nasabah yang loyal. Loyalitas nasabah dipengaruhi oleh Customer Relationship Management (CRM), hal ini disebabkan karena CRM sangat dibutuhkan dalam rangka menjalin hubungan pelanggan yang benar - benar akrab, sehingga sebuah perusahaan dapat mengetahui banyak hal terhadap pelanggannya. 
Saat ini kepuasan pelanggan adalah prioritas utam pada sebuah perusahaan guna menjadikan mereka sebagai penggan yang setia. Untuk mengubah mereka menjadi pelanggan seria diperlukan perhatian khusus guna memebrikan kepuasan yang terbaik untuk pelanggan. Dengan kepuasan ini maka akan memelikik peluang yang lebih besar untuk pelanggan datang kembali dan juga secara tidak langsung akan merekomendasikan kepada orang lain. Meningkatkan loyalitas, maka juga harus meningkatkan tingkat kepuasan setiap anggota dalam jangka panjang artinnya mereka puas dengan sesuatu yang telah diberikan perusahaan terhadapnya.

LPD merupakan sebuah lembaga dengan tugas pokok pada bidang ekonomi yang bertugas untuk menghimpun serta memebrikan sebuah penyaluran. Penyaluran yang dimaksud berupa dana kepada masyarakat setempat. Sehingga LPD dapat menjadi sebuah perantara atau hubungan seperti lalu lintas sebuah pembayaran yang pada umumnya serta menjadi sebuah sumber dalam pembiayaan pembangunan yang ada di daerah desa adat di Bali. Untuk mendorong sebuah pembangunan dalam sector ekonomi masyarakat maka dilakukan sebuah tindakan khusus yaitu menabung secara terarah atau terstruktur dan memebrikan sebuah modal guna memperoleh pekerjaan secara efektif.

\section{TELAAH LITERATUR DAN HIPOTESIS}

\section{Loyalitas}

Menurut Kotler dan Keller (dalam Rosiana, 2019), loyalitas atau sering disebut sebagai kesetiaan digambarkan sebagai sebuah komitmen yang dipegang dengan sangat kuat dalam memberi sebuah jasa atau produk yang dilakukan dimasa yang akan datang. Untuk meminimalisir terjadinya perbuhan kepada perilaku seseorang yang terjadi pada situasi tertentu.

\section{Customer Relationship Managemnet (CRM)}

Kotler dan Amstrong (2013:36) meenjelaskan bahwa CRM juga dianggap sebagai sebuah konsep yang sangat penting terhadap pemasaran di era modern. Dimana dalam arti yang lebih umum. Rainer dan Cegielski (2013:288) juka mengemukakan bahwa, CRM adalah sebuah strategi atau rencana dari organisasi yang berpusat serta berorientasi pada seorang pelanggan. Menurut Ali Hasan (2013:128), CRM diartikan sebagai sebuah persepsi seorang pelanggan dengan proporsional rasio dari suatu biaya dengan manfaat dari pada seorang pelanggan, rasio uang pada keuntungan yang ada dalam perusahaan serta sebuah hubungan berkelanjuan serta menjadi hubungan yang timbal balik. 


\section{Kepuasan}

Kepuasan (Satisfaction) merupakan suatu ekspresi dari penggan yang ditunjukkan dengan cara perasaan senang atau kecewa, setelah mempertimbangan sebuah knerja produk yang direncanakan dengan apa yang akan diharapkan. Andaikan sebuah knerja beradapada bagian terbawah pada sebuah hrapan maka planggan akan merasa belum terpuaskan. Menurut Hartiwi (2013) menyebutkan bahwa, ketika seorang pelanggan sudah terpuaskan sesuai pelayanan dilakukan atau mendapatkan hal yang sesuai pada proses transksi sedang berlangsung maka peluang besar mereka balik lagi dan memebli keperluan lainnya akan lebih besar juga. Rosy (2018) menyatakan bahwa kepuasan seorang planggan dapat ditentukan melalui sebuah knirja dilakukan pada produk yang sesuai dengan budget dari pembeli.

\section{METODE PENELITIAN}

Berdasarkan tinjauan pustaka, kerangka kerja konseptual yaitu:

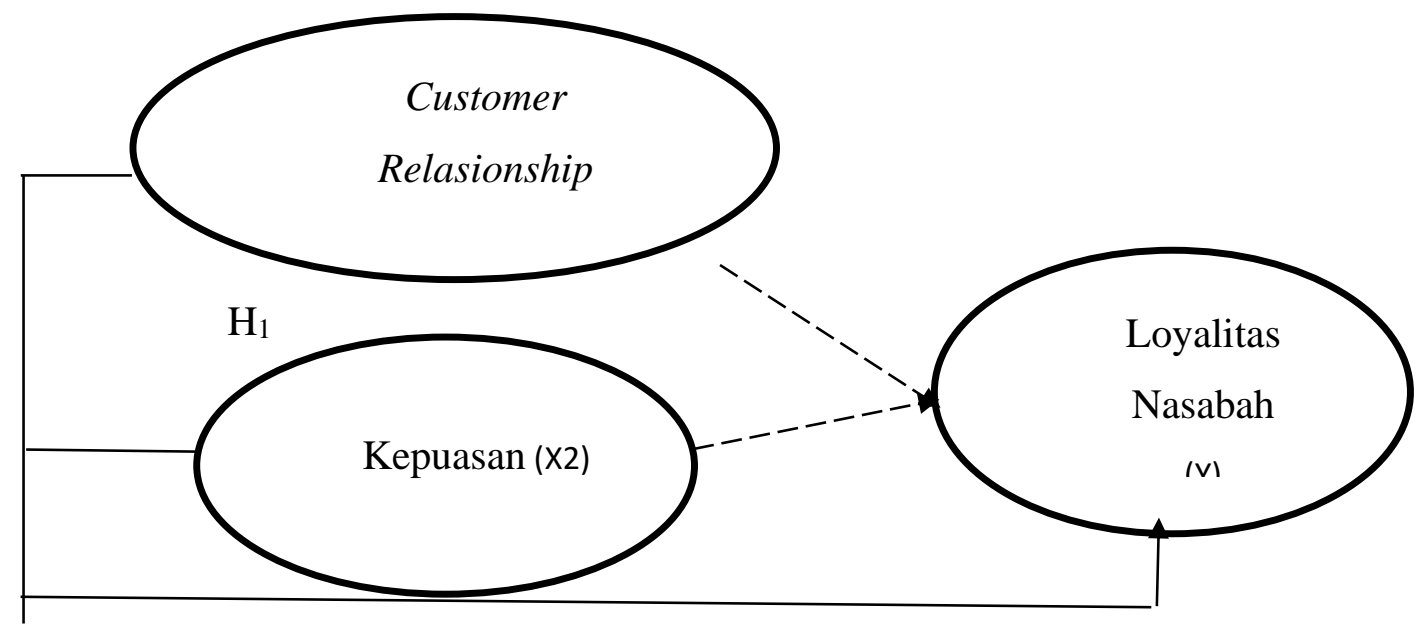

\section{Gambar 1 Kerangka Konseptual}

Sebagai kerangka kerja konseptual penelitian, hipotesis penelitian ini adalah:

1. Customer Relasionship management (CRM) berpengaruh positif dan signifikan terhadap LoyalitasNasabah Tabungan pada LPD Desa Adat Anggungan.

2. Kepuasan berpengaruh positif dan signifikan terhadap LoyalitasNasabah Tabungan pada LPD Desa Adat Anggungan. 
3. Customer Relasionship Management (CRM) dan Kepuasan mempunyai pengaruh positif dan signifikan terhadap LoyalitasNasabah Tabungan pada LPD Desa Adat Anggungan.

Populasi dari penelitian ini bertolak pada latar belaang masalah dimana nasabah tabungan pada LPDdesa adat anggungan di tahun terakhir yaitu 1.958 nasabah tabungan. Teknik penentuan sampel menggunakan rumus slovin diperoleh hasil sampel yaitu 95 rsponden. Data pada penelitian inidikumpulkan melaluikuesioner dan wawancara mendalam kepada responden. Selanjutnya data dikumpulakan dan dianalsisi menggunakan analisisi regresi linier berganda

\section{HASIL PENELITIAN DAN PEMBAHASAN}

Tabel 1. Uji Validitas dan Reliabilitas

\begin{tabular}{llllll}
\hline No & Variabel & Indikator & $\begin{array}{l}\text { Koefisien } \\
\text { Korelasi }\end{array}$ & $\begin{array}{l}\text { Koefisien } \\
\text { Batas }\end{array}$ & Keterangan \\
\hline $\mathbf{1}$ & Customer & $\mathrm{X} 1.1$ & 0,778 & 0,30 & Valid \\
& Relationship & $\mathrm{X} 1.2$ & 0,878 & 0,30 & Valid \\
& Management & $\mathrm{X} 1.3$ & 0,787 & 0,30 & Valid \\
$\mathbf{2}$ & Kepuasan & $\mathrm{X} 2.1$ & 0,813 & 0,30 & Valid \\
& Nasabah & $\mathrm{X} 2.2$ & 0,840 & 0,30 & Valid \\
& & $\mathrm{X} 2.3$ & 0,774 & 0,30 & Valid \\
& & $\mathrm{X} 2.4$ & 0,871 & 0,30 & Valid \\
$\mathbf{3}$ & Loyalitas & $\mathrm{Y} .1$ & 0,715 & 0,30 & Valid \\
& Nasabah & $\mathrm{Y} .2$ & 0,833 & 0,30 & Valid \\
& & $\mathrm{Y} .3$ & 0,886 & 0,30 & Valid \\
& & $\mathrm{Y} .4$ & 0,865 & 0,30 & Valid \\
\hline
\end{tabular}

Sumber: data diolah (2020)

Hasil analisis didapat hasil bahwa seluruh butir instrumen dapat dinyatakan valid. Hal tersebut dapat dinyatakan demikian karena seluruh koefisien korelasi lebih besar dibandingkan 0,30. sehingga data penelitiana dapat digunakan dalam analisis lebih lanjut.

\section{Uji Reliabilitas}

Tabel 2. Hasil Uji Reliabilitas Instrumen Penelitian

\begin{tabular}{llll}
\hline No. & Variabel & Cronbach's Alpha & Keterangan \\
\hline $\mathbf{1}$ & Customer $\quad$ Relationship & 0,712 & Reliabel \\
& Management $(\mathrm{X} 1)$ & & \\
$\mathbf{2}$ & Kepuasan Nasabah (X2) & 0,841 & Reliabel \\
$\mathbf{3}$ & Loyalitas Nasabah (Y) & 0,839 & Reliabel \\
\hline
\end{tabular}

Sumber: data diolah (2020) 
Hasil analisis pada tabel diatas mengidentifikasikan bahwa koefisien cronbachAlpha lebihdari 0,60. Sehingga semua variabel telah terpenuhi syarat reliabilitas dan bisa digunakan dalam melakukan penelitian

\section{Analisis Deskriptif}

Adapun persepsi reponden kepada Customer Relationship Management (CRM) dengan 3 butir pernyataan, Kepuasan Nasabah dengan 4 butir penyataan dan Loyalitas Nasabah dengan 4 butir pernyataan dijabarkan sebagai berikut:

\section{Deskripsi Variabel Customer RelationshipManagement}

Mengacu pada tabel, Customer RelationshipManagement mempunyai rata-rata keseluruhan yaitu 3,84 (kategori baik), skor terendah yaitu pada pernyataan "Karyawan LPD Desa Adat Anggungan mampu tetap menangani keluhan nasabah" yaitu 3,77 (kategori baik), sedangkan skor tertinggi yaitu pada pernyataan "Perusahaan memberikan undian berhadiah pada saat ulang tahun LPD Desa Adat Anggungan”yaitu 3,98 (kategori sangat baik).

\section{Deskripsi Variabel Kepuasan Nasabah}

Mengacu pada tabel, variabel KepuasanNasabah mempunyai average sebesar 3,96 dengan kategori baik, skor terendah yaitu pada pernyataan "LPD Desa Adat Anggungan tidak pernah membeda-bedakan nasabah dalam pelayanan" sebesar 3,64 dengan kategori baik, sedangkan skor tertinggi yaitu pada pernyataan "Tingkat bunga yang ditetapkan LPD Desa Adat Anggungan baik kredit maupun tabungan cukup kompetitif dan menarik" sebesar 4,14 dengan kategori baik.

\section{Deskripsi Variabel Loyalitas Nasabah}

Mengacu pada tabel, variabel LoyalitasNasabah memiliki average keseluruhan yaitu 3,94 (kategori baik), skor terendah yaitu pada pernyataan "Saya akan menyarankan keluarga atau sahabat untuk menggunakan produk/jasa yang dimiliki oleh LPD Desa Adat Anggungan” sebesar 3,84 dengan kategori baik, sedangkan skor tertinggi yaitu pada pernyataan "Saya akan tetap bertahan dengan produk/jasa dari LPD Desa Adat Anggungan meskipun ada promosi dari perusahaan lain” sebesar 4,00 dengan kategori sangat baik. 


\section{Uji Asumsi Klasik}

\section{Uji Normalitas}

Tabel 3. Uji Normalitas

\begin{tabular}{lll}
\hline One-Sample Kolmogorov_Smirnov Test & \\
\hline & & Unstandardized Residual \\
$\mathrm{N}$ & & 95 \\
Normal Parameters ${ }^{\mathrm{a}, \mathrm{b}}$ & Mean & .0000000 \\
& Std. Deviation & 1.58457591 \\
& & \\
Most Extreme Differences & Absolute & .082 \\
& Positive & .082 \\
Test Statistic & Negative & -.058 \\
Asymp. Sig. (2-tailed) & & .082 \\
\hline
\end{tabular}

Sumber: data diolah (2020)

Mengacu pada table bahwa nilai KolmogorovSminarnov (K-S) adalah 0,082, sedangkan nilai AsympSig, (2 jalur) adalah 0,121. Artinya model persamaan regresi ini terdistribusi secara normal karena nilai AsympSig, (2 jalur) $(0,121>0,05)$.

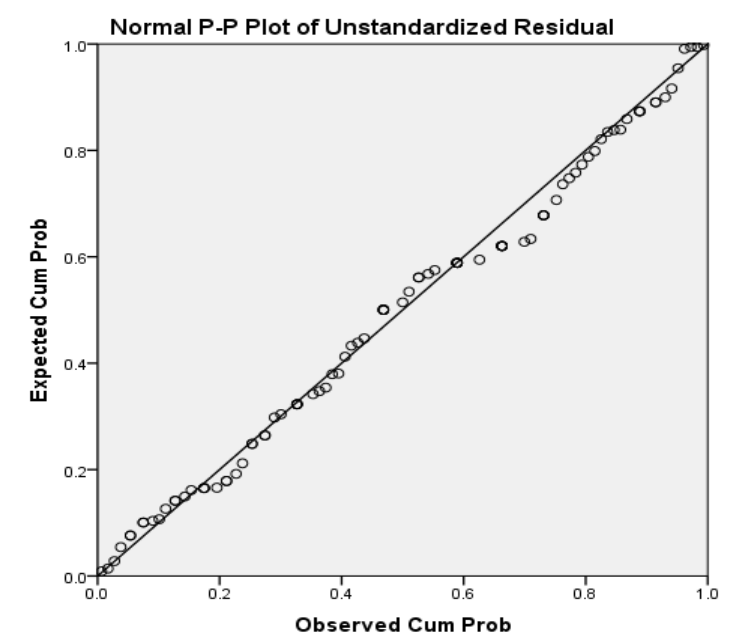

Gambar 2. Grafik Normal Probability Plot 
Mengacu pada gambar, titik-titik yang terlihat pada gambar membentuk sebuah pola. Jika ditarik garis lurus akan terbentuk sebuah garis dengan bentuk diagonal jika membandingkan antara garis diagonal dengan ploting maka dapat disimpulkan residual data berdistribusi normal.

\section{Uji Multikolinieritas}

\section{Tabel 4. Uji Multikolinieritas}

\section{Coefficients $^{\mathrm{a}}$}

\begin{tabular}{|c|c|c|c|}
\hline \multirow{2}{*}{\multicolumn{2}{|c|}{ Model }} & \multicolumn{2}{|c|}{ Collinearity Statistics } \\
\hline & & Tolerance & VIF \\
\hline 1 & Customer Relationship Management & .534 & 1.871 \\
\hline & $\begin{array}{l}\text { Kepuasan Nasabah } \\
\text { ependent Variable: Lovalitas Nasabah }\end{array}$ & .534 & 1.871 \\
\hline
\end{tabular}

Mengacu pada table 4 bahwa nilai disetiap tolerance variabel Customer RelationshipManagement dan Kepuasan Nasabah melebihi 0,10 sedangkan nilaiVIF dibawah 10 ini berarti tidak ada multikolenearitas.

\section{Uji Heteroskedastisitas}

Tabel 5. Uji Heteroskedastisitas

\begin{tabular}{llll}
\hline Model & $\mathbf{t}$ & Sig. \\
\hline 1 & (Constant) & 3.307 & .001 \\
& Customer Relationship Management & .593 & .554 \\
& Kepuasan Nasabah & -1.724 & .088 \\
\hline
\end{tabular}

Sumber: data diolah (2020)

Mengacu pada table 5 bawah nilai sig pada variabel Customer RelationshipManagement yaitu 0,554 (0,554 > 0,05), nilai sig pada variabel Kepuasan Nasabah adalah 0,088 (0,088 > 0,05), hal ini mengartikan bahwa tidak terjadi heterokedatitas.

\section{Hasil Analisis Regresi Linier Berganda}

Mengacu pada tabel, bentuk persamaan struktural adalah: $Y=1,411+0,242 \mathrm{X}_{1}+0,730 \mathrm{X}_{2}+0,091$

Nilai koefsien sesuai persamaanregresi variabel CustomerRelationship Management dan KepuasanNasabah memiliki pengaruh positif dengan nilai sig pada uji t lebih kecil dari 0,05, sehingga variabel CustomerRelationship Management serta KepuasanNasabah memiliki pengaruh positif serta signifikan kepada variabelLoyalitas Nasabah. 


\section{Tabel 6. Uji Regresi Berganda}

\begin{tabular}{|c|c|c|c|c|c|c|}
\hline \multicolumn{7}{|c|}{ Coefficients $^{\mathbf{a}}$} \\
\hline \multirow{2}{*}{\multicolumn{2}{|c|}{ Model }} & \multicolumn{2}{|c|}{$\begin{array}{l}\text { Unstandardized } \\
\text { Coefficients }\end{array}$} & \multirow{2}{*}{$\begin{array}{l}\text { Standardized } \\
\text { Coefficients } \\
\text { Beta }\end{array}$} & \multirow[t]{2}{*}{$\mathrm{T}$} & \multirow[t]{2}{*}{ Sig. } \\
\hline & & $\begin{array}{l}\mathrm{B} \\
1.411\end{array}$ & $\begin{array}{l}\text { Std. Error } \\
1.117\end{array}$ & & & \\
\hline & $\begin{array}{l}\text { Customer Relationship } \\
\text { Management }\end{array}$ & .242 & .114 & .179 & 2.127 & .036 \\
\hline & Kepuasan Nasabah & .730 & .091 & .674 & 8.005 & .000 \\
\hline $\mathrm{R}$ & & 0.807 & & & & \\
\hline & quare & 0.651 & & & & \\
\hline & usted R Square & 0.644 & & & & \\
\hline & itung & 85.926 & & & & \\
\hline & & 0.000 & & & & \\
\hline
\end{tabular}

Sumber: data diolah (2020)

\section{Hasil Uji Pengaruh Simultan Uji F (F-test)}

Berdasar hasil bahwa nilai Sig. 0,000 serta nilai F hit > F tabel $(85,926>3,09)$, sehingga Customer RelationshipManagement dan KepuasanNasabah fisik secarasimultan berpengaruh kepada LoyalitasNasabah di LPD Desa Adat Anggungan.

\section{Hasil Uji Pengaruh Parsial uji t (t-test)}

\section{Pengaruh Customer Relationship Management terhadap Loyalitas Nasabah Karyawan}

Nilai Sig adalah 0,036 dan nilai koefisien regresi aalah 0,242 serta t hit > t tabel $(2,127>1,661)$, sehingga CustomerRelationship Management memiliki pengaruh positif dan sgnifikan kepada LoyalitasNasabah karyawan di LPD Desa Adat Anggungan

\section{Pengaruh Kepuasan Nasabah terhadap Loyalitas Nasabah Karyawan}

Mengacu pada tabel nilai Sig adalah 0,000 dan nilai koefisienregresi adalah 0,730 serta t hit $>\mathrm{t}$ tabel $(8,005>1,661)$, sehingga KepuasanNasabah berpengaruh positif serta sgnifikan kepada LoyalitasNasabah di LPD DesaAdat Anggungan 


\section{Hasil Analisis Koefisien Determinasi}

\section{Tabel 7.Analisis Koefisien Determinasi}

\begin{tabular}{llllll}
\multicolumn{2}{l}{ Model Summary } & \\
\hline Model & $\mathrm{R}$ & R Square & Adjusted R Square & $\begin{array}{l}\text { Std. Error of the } \\
\text { Estimate }\end{array}$ \\
1 & $.807^{\mathrm{a}}$ & .651 & .644 & 1.602 & \\
\hline
\end{tabular}

Sumber: data diolah (2020)

Mengacu pada tabel, nilaideterminasi total (Adjused RSquare) yaitu 0,530 mengartikan bahwasebesar 53,0\% variabel LoyalitasNasabah dipengaruhi oleh variabel CustomerRelationship Management dan loyalitasNasabah, sedangkan sisanya47,0\% dipengaruhioleh faktor lain.

\section{Pembahasan}

\section{Pengaruh Customer RelationshipManagement Terhadap Loyalitas Nasabah}

Berdasar hasil analisis data didapat bahwa nilai sgnifikansi sebesar $(0,036<0,05)$, dengan nilaikoefisien regresisebesar 0,242, Hasil ini mempunyai arti bahwa Customer RelationshipManagement secara parsial mempunyai pengaruh positif serta sgnifikan kepada LoyalitasNasabah pada LPD DesaAdat Anggungan. Customer RelationshipManagement memilikipengaruh positif serta sgnifikan kepada LoyalitasNasabah pada LPD Desa Adat Anggungan. Hal tersebut berarti setiap peningkatan Customer RelationshipManagement maka akanterjadi peningkatan Loyalitas Nasabah LPD DesaAdat Anggungan

\section{Pengaruh KepuasanNasabah Terhadap Loyalitas Nasabah}

Berdasar hasil analisis data bahwa nilai sgnifikansi $(0,000<0,05)$, dengan nilaikoefisien regresi yaitu 0,730. Mengartikan bahwa Kepuasan Nasabahsecara parsial mempunyai pengaruh positifdan sgnifikan kepada LoyalitasNasabah pada LPD DesaAdat Anggungan. KepuasanNasabah memiliki peng positif serta sgnifikan kepada Loyalitas Nasabah pada LPD DesaAdat Anggungan. Hal tersebut berarti setiap peningkatan Kepuasan Nasabah maka akan terjadi peningkatan LoyalitasNasabah pada LPD DesaAdat Anggungan

Pengaruh Customer RelationshipManagement dan KepuasanNasabah Terhadap Loyalitas Nasabah

Berdasarkan hasil analisis data diperoleh nilai $F_{\text {hitung }}>F_{\text {tabel }}, 85,926>3,09$, dengan nilai sig, $0,000<0,05$, Hal ini menunjukan bahwa ada pengaruh yang positif dan sgnifikan secara 
simultan antara Customer RelationshipManagement dan KepuasanNasabah secara bersama kepada LoyalitasNasabah pada LPD Desa Adat Anggungan. Customer Relationship Management dan KepuasanNasabah secara bersamaan berpengaruh positif dan sgnifikan kepada LoyalitasNasabah pada LPD Desa Adat Anggungan. Hal tersebut berarti setiap peningkatan CustomerRelationship Management serta Kepuasan Nasabahsecara bersamaan maka akan terjadi peningkatan LoyalitasNasabah pada LPD DesaAdat Anggungan

\section{SIMPULAN}

Dari hasil dan pembahasan maka didapat simpulan hasil penelitian yang dilaksanakan di LPD Desa Adat Anggungan adalah sebagai berikut,

1. Ada pengaruh positif dan sgnifikan antara Customer Relationship Management terhadap Loyalitas Nasabah pada LPD Desa Adat Anggungan, yang artinya semakin baik Customer RelationshipManagement yang diberikan, maka akan terjadi peningkatan

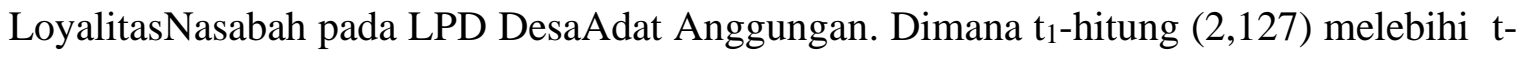
tabel $(1,661)$ dan nilaisig 0,036 maka hipotesis diterima.

2. Ada pengaruh positif dan sgnifikan antara Kepuasan Nasabah terhadap LoyalitasNasabah pada LPD Desa Adat Anggungan, yang artinyasemakin baik Kepuasan Nasabah yang diberikan, akan terjadi peningkatan LoyalitasNasabah pada LPD Desa Adat Anggungan. Dimana $\mathrm{t}_{2}$-hitung $(8,005)$ melebihi $\mathrm{t}$-tabel $(1,661)$ dannilai sig 0,000 maka hipotesis diterima.

3. Ada pengaruh positif serta sgnifikan antaraCustomer RelationshipManagement dan KepuasanNasabah secara simultan berngar terhadap LoyalitasNasabah pada LPD DesaAdat Anggungan. Hal tersebut berarti setiap peningkatan Customer RelationshipManagement dan KepuasanNasabah secara bersamaan akan meningkatkan pula LoyalitasNasabah pada LPD Desa Adat Anggungan. Dimana F-hitung $(85,926)$ melebihi F-tabel $(3,09)$ dannilai sig 0,000 maka hipotesis diterima.

\section{Saran}

Berdasar simpulan yang telah dipaparkan, maka dapat dirangkum saran sebagai berikut,

1. Customer Relationship Management 
Karyawan LPD Desa Adat Anggungan hendaknya mampu mengoptimalkan mengoptimalkan keluhan nasabah tabungan, hal tersebut akan dapat menciptakan loyalitas nasabah.

2. Kepuasan

Karyawan LPD Desa Adat Anggungan hendaknya bisa memberikan pelayanan yang puas kepada nasabah, hal tersebut akan menciptakan loyalitas kepada nasabah.

\section{Loyalitas}

Untuk menciptakan loyalitas nasabah hendaknya Karyawan LPD Desa Adat Anggungan memberikan pelayanan yang maksimal, sehingga nasabah tersebut mau merekomendasikan LPD desa adat anggugan kepada keluarga atau sahabat untuk menggunakan produk/jasa yag dimiliki.

\section{DAFTAR PUSTAKA}

AliHasan. 2013.Marketingdan Ksus-Kasus Pilihn. Yogykarta: CAPS(Centerfor AcademicPublishing Service).

Amstrong dan Kettler. 2013. Prinsip-Prinsip Pemasaran. Edisi 12. Jakarta: Erlangga.

Cravens, W dan David. 1996.Pemsaran Strategi. Jilid1. Edisi 3. Jakarta: Erlangga.

Griffin. 2005. CustomerLoyalty, menumbuhkandan mempersatukan kesetiaan pelanggan. Jakarta: Erlangga.

Imam. G. 2005. Aplikasi Multivariate dengan programSPSS. Semarang: Badan PenerbitUniversitas Diponogoro.

Imam. G. 2007. Aplikasi Multivariate dengan program SPSS. Semarang: Badan Penerbit Universitas Diponogoro.

Imam. G. 2013. Aplikasi Multivariate dengan program IBNA SPSS21 UpdatePLS Regresi.

Semarang: Badan Penerbit Universitas Diponogoro.

Kotler. 2012. Manajemen Pemasaran. Edisi12. Jakarta: Erlangga.

Kotler. 2010. Manajee Pemasaran.Edisi13 Bahasa Indonesi. Jilid 1dan2. Jakarta: Erlangga.

Kertajaya, H. 2013.Tourism Marketing. Jakarta: PT. Gramedia Pustaka Indonesi.

Kalakota., Ravi, dan Robison, M. 2001. E. Business2.0:Roadmap of sucess. AddisonWesley, LongmanInc. USA.

Mangkunegara. 2002. Manajemen Sumber DayaManusia Perusahaan. Edisi 2. Bandung:

RemajaRosdakarya Offset.

Mangkunegara, A. 2002. ManajemenSumber DayaManusia Perusahaan. Bandung:

RemajaRosdakarya Offset.

Rosiana, N. W. A. 2019. Peran Kepuasan Nasabah pada memediasi Pengaruh Customer 
Relationship Management (CRM) terhadap Loyalitas Nasabah Koperasi Simpan Pimjam Pradnya Sedana Mandiri, di Badung. Skripsi. Universitas Hindu Indonesia.

Rainer, R. K., dan Cegieski, C. G. 2013. Introdiction of information system, Fourt Edition. Singapore: Jhon Wiley and Sons Singapore pte, Itd

Sabar, R, 2007. PengantarMetodologi Penelitian.FKIP: Universitas Nuria Kudus.

Sari, N. P., Daryanto.H. K., dan Saptono, I. Pt. 2018. Pengaruh CRM Trhadap kpuasan danloylitas Nsabah PT.Bnk BNI. Jurnal Aplikasi Mnajemen dn Bisnis, V1. 4, NO. 1, pp: 129-137.

Sagiyono. 2011. Metode Penelitian Kuantitatif,Kualitatif danR \& D. Alfabeta.

Saifudin. 20011. MetodePenelitian, Yogyakarta: Pustaka Pelajar.

Setyalaksan 2017. Pengaruh CRM terhadap Kepuasan Pelanggan. http://www.repositor.ac.id. Diunduh pada tanggal 27 Oktober 2019.

Suasana, I. G., dan Gorda,S. E. 2017. PengaruhPelayanan Prima dan Customer RelationshipManagement TerhadapLoyalitas Pasien yang dimesiasi oleh kepuasandan kepercayan. JurnalManajemen danBisnis ISSN: 1829-8484, Vol. 14, No 1, Pebruari 2017, pp: 56-74.

Tjiptono. 2015. Strategi Pemasarn. Yogyakarta: Penerbit Aandi.

Tjiptono. 2011. Manajemen dan Strategi Merek. Yogyakarta: Aandi Afset.

a. Sumber kutipan yang berasal dari asosiasi atau institusi sebaiknya menyebutkan akronim asosiasi atau institusi yang bersangkutan, misalnya (ISEI, 2011:10). 